\title{
Pancasila as the Foundation of Educational Philosophy in Indonesia
}

\author{
I Ketut Sudarsana ${ }^{1}$, Ni Kadek Surpi ${ }^{2}$, Khoirotul Badriyah ${ }^{3}$, Rosida Tiurma Manurung ${ }^{4}$, I \\ Nyoman Piartha ${ }^{5}$, Haimah ${ }^{6}$, Ida Nuryana ${ }^{7}$, I Wayan Sukabawa ${ }^{8}$, Ricardo Freedom Nanuru ${ }^{9}$ \\ \{1 iketutsudarsana@uhnsugriwa.ac.id\} \\ ${ }^{1,2,5,8}$ Universitas Hindu Negeri I Gusti Bagus Sugriwa Denpasar, Bali, Indonesia, ${ }^{3}$ Paud Permata Bunda \\ Taba Tembilang, Bengkulu, Indonesia, ${ }^{4}$ Universitas Kristen Maranatha, Indonesia, ${ }^{6}$ Universitas Prof. \\ DR. Hazairin, SH, Bengkulu, Indonesia, ${ }^{7}$ Universitas Kanjuruhan Malang, Indonesia, ${ }^{9}$ Universitas \\ Kristen Indonesia Maluku. Ambon, Indonesia
}

\begin{abstract}
Today, education tends to only be interpreted as a learning process in formal schools and education is only interpreted as a process of learning and teaching by teachers and students. This phenomenon is very common where people only interpret education as limited to an ordinary routine that must be done without understanding that there is a benefit in it. This kind of thinking turned out to be a time bomb when the symptoms began to get lazier in understanding the education community and began to lazy the students to learn and began to notice the reluctance of education stakeholders and organizers to build and improve the quality of education in Indonesia.
\end{abstract}

Keywords: Pancasila; Educational Philosophy

\section{Introduction}

In print and electronic media, there are often news that presents how the quality of education in Indonesia has begun to be in disarray with the number of actual events that are very sad to see and witness. The number of brawl events carried out by teenagers who incidentally have been taught character education in schools which should be able to shape the character of students into better characters characterized by behavioral changes towards a better direction [1]. Bullying in schools that afflicts students due to the system of seniority and juniority in the school environment makes it even more apparent that education in Indonesia is beginning to show its quality is decreasing day by day.

What really happens with education in Indonesia. When science and technology are increasingly advanced, the human mindset should be more advanced and developing and it should be with these advances ideally to generate enthusiasm in carrying out educational activities to increase competence in preparation for facing the world.

The impact of globalization which increasingly shows a kind of chaos in the development of the competence of individuals is not accompanied by the awareness that in addition to being built is the development of infrastructure that is also built is a mental development and the development of better-quality education [2] [3].

Education providers and policy makers should begin to break down to build the quality of Indonesian human development that has competitive qualities and a winning mental quality to be able to face the global upheaval [4]. Apart from that, individuals must also begin to realize that education is important that education is not just a routine but that there is an idea of 
humanity in it and the community must also begin to realize that development is not only the responsibility of the government, but also a shared responsibility to create harmony and the creation of good cooperation between the government and the community in building Indonesian education with the character in accordance with the government's mandate of an idea of mental revolution.

\section{Method}

This study uses a qualitative approach with library research methods. Data collection was carried out by studying relevant libraries that gave rise to human beings who were humanist and religious. The data analysis technique used is content analysis or content analysis. Data analysis can also be done through data display stages, data reduction, data verification and conclusions

\section{Result and Discussion}

The problem in this paper is the philosophical background in education in Indonesia. When discussing a problem there is a reason to discuss each of the substance of the problem, namely education, the foundation of education and its philosophical foundation to bring the end and base of the problem and how it is discussed.

As a process in education it is necessary to have a foundation or guidance that applies so that education as a development process can run and be arranged in accordance with the objectives to be achieved [5]. When referring to the goal, education in Indonesia emphasizes the purpose of intellectualizing the life of the nation intellectually, emotionally and spiritually according to the mandate of the 1945 constitution.

The foundation as a guide is the basis of an educational process itself. The foundation in the Big Indonesian Dictionary is interpreted as a basis that provides direction and guidance. So the foundation here can be interpreted as a rule that underlies and gives the foundation for the implementation and achievement of the purpose of the activities carried out and in this case education itself.

The foundation as a guide has two interrelated dimensions namely a foundation that functions as a concept or theoretical and a foundation that serves to give spirit or spirit or philosophy [6]. The foundation as giving spirit or enthusiasm is the foundation that gives the soul so that the educational process does not only function as a form of intellectual knowledge but a philosophical foundation is useful to provide direction on the formation of knowledge that leads to the development of emotional and spiritual knowledge.

Philosophical in the meaning of the word is the development of the word philosophy. Philosophy is believed to have originated in the days of Ancient Greece. According to the conception of the great Greek philosopher, Aristotle stated that philosophy is a theoretical knowledge that examines eternal changes that are not changed and separate from the material by Aristotle defines it as "the science og first principle" [7] [8]. So philosophical or philosophy is a theoretical knowledge that relies on or is guided by unchanging and eternal principles.

Furthermore it was stated that the word philosophy came from the ancient Greek philos and shopia which meant love and wisdom. According to the meaning of the word, philosophy is a love of wisdom [7]. So that it translates to the meaning of the word philosophy, it can be interpreted as a science or teaching that attaches importance to a love of wisdom ideas and wisdom that emphasizes the process of truth seeking.

In line with this conception, the philosophical foundation as one of the foundations in education is to emphasize the demand in seeking wisdom and the process of seeking the truth 
to lead to the essential truth itself. So that the philosophical foundation is a guideline that relies more on the essence of education which has a very deep meaning.

Indonesia as a country formed from the struggle of the founding father or founder of this nation has its own philosophy. This philosophy is formed and taken from local Indonesian wisdom itself which is a noble soul and value that has existed since ancient times and has taken root. The philosophy by the founders of the nation was then compiled to become the basis of the State which until now was trusted and used as guidance in the nation and state. The philosophy is Pancasila.

Pancasila is the spirit of the nation, Pancasila is also a rule that is believed, Pancasila is a basic law that binds Indonesia itself. Pancasila itself is not taken from the conception of other nations, but taken from existing, born and rooted values of the Indonesian nation itself. Pancasila was echoed by the founders of the Indonesian nation, where the contents and concepts were noble agreements [9].

Pancasila itself was formed and was first spoken by Ir. Soekarno which means five basic or five rules. These five rules used to be and now differ in content. If we examine the history of the process of creating Pancasila as the basis of the State, there is a fundamental polemic which has caused tension among the founders of the nation. This is because there are differences in views on the first principle, namely the Belief in the One and Only God, where in the Jakarta Charter, the First Principle was the Belief in the One and Only God by carrying out Islamic Shari'a, but because of a bit of protest and a spirit of tolerance because Indonesian pluralism is finally changed as we accept now.

Moving on from there it can be said that the Pancasila is a basic law or basic rule that becomes the spirit and soul of the Indonesian people in carrying out their daily activities. This can make that the philosophical foundation of Indonesian education is the Pancasila itself. Why, because the Pancasila is a law and a basis that respects all areas of Indonesian life. From the Pancasila, there is a conception and symbolism of how Indonesian education should be given. Pancasila as a basis there are five fundamental values, namely religious values or beliefs related to spiritualism, the value of socialism, namely humanity and tolerance, the value of nationalism, namely national unity, the value of the agreement to reach consensus through deliberation and patriotism or justice for the welfare of Indonesia [10]. These five values should be used in education as the soul of Indonesian education itself, the spirit of Pancasila should synergize with education itself. Because education is not just an activity without meaning but a life-long activity. The conception of the five values can be assumed as follows. The value of religious spiritualism in the first principle in education aims to provide direction that Indonesian education not only forms an intelligent human being but forms a mentally mature and spiritually mature human. Religion, the belief system in Indonesia, should be able to provide a conception of teachings that can be adapted as one of the goals of the formation of individuals who are noble and have faith in God. Religious values in education will shape people who have a religious spirit, have faith and noble character.

The value of social humanity. Humans as social beings are creatures who cannot live alone without help from others. The value of humanity in education according to the concept of the second principle of Pancasila is to give the soul that education in Indonesia emphasizes the emergence of a sense of humanity that Indonesian society is a community of brothers in the Indonesian environment, there is no fundamental difference that difference is the real unifier. The social value as a foundation is to build the spirit of humanitarian education to form socialist and non-individual individuals. The value of nationalism in the conception of the second principle of Pancasila in Indonesian education must provide a spirit of unity. That Indonesian education forms individuals who love the homeland, are united in differences and 
arouse the spirit of nationalism and respect the struggle of the heroes. The value of nationalism in education in Indonesia must be raised to foster the spirit that individuals in Indonesian territory are one and united in the unity of Indonesia itself. The spirit of educational nationalism must exist and rise as a monumental and fundamental movement of the Indonesian nation itself.

Political value, the spirit of deliberation to reach consensus. In the true sense, political value is not negative. Political value is a way to achieve the nation's own welfare goals. Indonesia is a democratic country where Indonesian society is a society that shares all the opinions of each individual, Indonesian society is the same society and has the same duties and rights. The system of democratic governance is a government system that aims to reach consensus in the form of deliberation. As strong as the value of this principle in education is to aim that every education policy and process of implementation is to reach agreement and achieve good quality of education which is carried out through deliberation. This value in education is very important to form individuals who have a democratic spirit.

The value of justice and patriotism in the conception of the five principles of Pancasila in education illustrates that Indonesian education is aimed at educating the life of the nation where education is equal in every individual citizen and nation of Indonesia. The spirit of this value is to give the spirit that education is the rights and obligations of the Indonesian people, there are no classifications and distinctive strata, anyone who has the right and does not have the right to education, the spirit of this value is to provide justice and equality that each Indonesian society has in common the right to get education itself. The spirit of Pancasila values in life must be a philosophical guide to form education that has good quality in Indonesia. In line with the program to realize character education is to start making Pancasila as the foundation and guidance of education itself [11] [12]. To achieve the goal of character education to form individual maturity that behaves well, the Pancasila is a definite law in Indonesian education itself.

The hypothesis in the integration of Pancasila as the philosophical foundation of education in Indonesia is likely to be able to provide views and guidance to direct education as an individual's maturation process towards the nation's character education, in addition to the integration of Pancasila as an educational foundation then all the problems that hit Indonesian education with all the chaos it can be overcome slowly. This problem occurs because Indonesians are starting to distrust and abandon the value of Indonesian wisdom itself, namely Pancasila with the many phenomena of the emergence of coercion of ideologies of other nations who want to undermine Pancasila ideology as the ideology of the nation which is one of the causes of individual problems including education. So by making and awakening the spirit of Pancasila as the foundation of Indonesian education can be trusted the aim of Indonesian education to educate the life of the nation and realize the process of character education in the spirit of nationalism in line with the mental revolution program can be realized.

\section{Conclusion}

From the long and wide description of the above issues related to the foundation of education in Indonesia, it can be concluded that :

a) The foundation of education not only covers the theoretical and practical domains but also must look at the philosophical domain.

b) Education is not only aimed at forming intelligent individuals intellectually only but also emotionally intelligent and spiritually intelligent. 
c) The foundation of education in Indonesia is the Pancasila itself which is a conception and law as well as the basic rules formed by the founders of the nation which are taken from the value of Indonesian wisdom itself.

d) The five principles in the conception of Pancasila values should be integrated and become the foundation in the procession of the implementation of education in the goals of Indonesian education characterized by the spirit of mental revolution.

\section{References}

[1] S. Judiani, "Implementasi Pendidikan Karakter di Sekolah Dasar melalui Penguatan Pelaksanaan Kurikulum," J. Pendidik. dan Kebud., 2010.

[2] Mohammad Imam Farisi, "Struktur Kurikulum Pendidikan Guru untuk Mengembangkan Kompetensi Guru yang Berkarakter dan Berbasis Budaya,” TING II. 2010.

[3] S. Adiwikarta, Peran dan Strategi Dasar Pendidikan DalamPeningkatan Sumber Daya Manusia. Seminar Nasional Tentang UpayaPengentasan Kemiskinan di Desa Terpencil. Bandung: IKIP Bandung, 1994.

[4] E. Rohendi, "Pendidikan Karakter Di Sekolah," EduHumaniora J. Pendidik. Dasar, 2011.

[5] K. U. Sukardjo, M, Landasan Pendidikan Konsep dan Aplikasinya. Jakarta: PT Rajagrafindo Persada, 2013.

[6] M. Pidarta, Landasan Kependidikan Stimulus Ilmu Pendidikan Bercorak Indonesia. Jakarta: Rineka Cipta, 2013.

[7] T. L. Gie, Pengantat Ilmu Filsafat. Yogyakarta: Libertysu, 2012.

[8] jujun S. Suriasumantri, Pengantar Filsafat Ilmu. 2009.

[9] Kurnisar, "Pancasila Sumber Dari Segala Sumber Hukum," J. Ilm. Ilmu Sos., 2012.

[10] S. Soeprapto, "Implementasi Pancasila Dalam Kehidupan Ber Masyarakat Berbangsa Dan Bernegara," J. Ketahanan Nas., 2016.

[11] S. Amir, "Pancasila as Integration Philosophy of Education And National Character," Int. J. Sci. Technol. Res., 2013.

[12] Ihsan, "Kecendrungan Global Dalam Proses Pembelajaran Pendidikan Pancasila dan Kewarganegaraan di Sekolah,” Pancasila dan Kewarganegaraan, 2017. 